\title{
Isohemagglutinin Anti-B
}

National Cancer Institute

\section{Source}

National Cancer Institute. Isohemagglutinin Anti-B. NCI Thesaurus. Code C97348.

An antibody that is reactive towards the B antigen present on the surface of some red blood cells. They are usually Ig M antibodies and are isoantibodies, antibodies produced by an individual against antigens produced by members of the same species (isoantigens). 